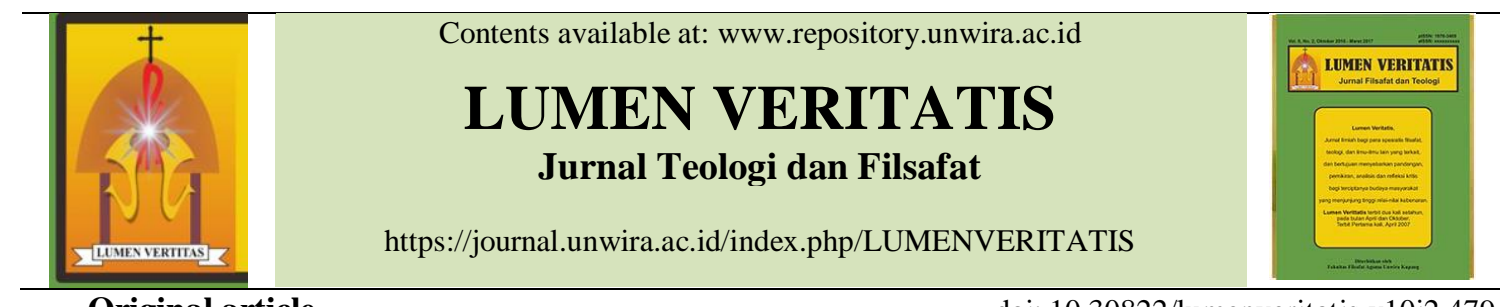

Original article

doi: 10.30822/lumenveritatis.v10i2.479

\title{
EKO-FENOMENOLOGI: LOGOS PARTISIPATIF DAN TABERNAKEL SEMESTA
}

\author{
Yasintus T. Runesi \\ Program Studi Ilmu Filsafat, Fakultas Filsafat, Universitas Katolik Widya Mandira \\ Email: sintusrunesi@gmail.com
}

\begin{abstract}
The natural environment suffered under dominion of science, mother earth in distress and progress is no longer treated as sacrosanct. This is calling for our responsibility, and requires more serious attention from all parties, at all levels of spheres of life. In this article, I will be presented a programmatic reading of the ecological and environmental crisis from phenomenological perspective. In the first part, it will be shown that this crisis is rooted in naturalisme, i.e dualistic point of views. As a critique of this form of thoughts, a theoretical response will be demonstrated through ecophenomenology as an interdisciplinary theory in the second part of this article, which followed by a reformulation of the concept of logos (reason) in the third part of this article based on concept logos of life from Anna-Teresa Tymieniecka and Henryk Skolimowski's participatory mind. The fourth part is a reflection of creation as a tabernacle of the universe, a place where the divine name resides, and will be closed with a small conclusion.
\end{abstract}

Keywords: Ecological crisis, naturalism, Tymieniecka, Skolimowski, participatory logos, the tabernacle of the universe

\section{Pendahuluan}

Fransiskus dalam ensikliknya, Laudato $\mathrm{Si}$ ', secara fenomenologis menyatakan bahwa bumi sedang "menjerit karena segala kerusakan yang telah kita timpakan padanya, karena penggunaan yang tak bertanggung jawab serta penyalahgunaan semua kekayaan yang telah diletakkan Allah di dalamnya".

\footnotetext{
1 Pope Francis, Encyclical Letter Laudato $\mathrm{Si}$, $\quad$ no. $2 . \quad$ Akses dari
} http://www.vatican.va/content/francesco/en/ency clicals/documents/papa-

francesco_20150524_enciclica-laudato-si.html. Kristóf Oltvai dalam pembacaannya atas dua dokumen Paus Fransiskus, Evangelii Gaudium dan Amoris Laetitia, mencatat bahwa dalam membangun gagasannya tentang perjumpaan interpersonal, Paus Fransiskus dipengaruhi oleh gagasan Emmanuel Levinas dan Jean-Luc
Dari perspektif imani, kehancuran ini mencerminkan realitas keberdosaan dan kebatilan yang menyekap seluruh kesadaran manusia sehingga tidak mampu bertindak secara tepat berhadapan dengan alam. Masih dalam bagian yang sama, Fransiskus menunjukkan kalau perlakuan yang dialami oleh alam ini sama dengan perlakuan manusia terhadap mereka yang miskin dan tersingkir. Dengan kata lain, Fransiskus hendak menegaskan

Marion. Saya menemukan kalau dalam Laudato $\mathrm{Si}^{\prime}$ juga jejak tersebut masih bisa ditemukan. Lih. Kristóf Oltvai, "Bergoglio among the Phenomenologists: Encounter, Otherness, and Church ini Evangelii Gaudium and Amoris Laetitia," Open Theology Vol. 2 (2018), 316324. 
bahwa marjinalisasi dan eksploitasi atas alam seiring sejalan dengan marjinalisasi dan eksploitasi terhadap orang-orang kecil, miskin dan terpinggirkan atau mereka yang dianggap tidak termasuk dalam bentuk-bentuk kalkulasi kemajuan ekonomi. Fransiskus mencatat bahwa "kita tidak berhadapan dengan dua krisis yang terpisah, yang satunya lingkungan hidup dan yang lainnya sosial, tetapi dengan satu krisis yang kompleks, yakni sosial dan lingkungan". ${ }^{2}$

Dalam konteks Indonesia, apa yang diungkapkan oleh Fransiskus merupakan pengalaman nyata, sesuatu yang dialami sebagai peristiwa yang sedang berlangsung. Penghancuran lingkungan hampir pasti berbaris iring dengan penghancuran kehidupan masyarakat tradisional. Anna Lowenhaupt misalnya, mencatat dalam hasil penelitiannya bahwa masyarakat Dayak Meratus yang menetap di sekitar gunung Meratus (Kalimantan Selatan) kehilangan hal-hal dasar yang menopang kehidupan mereka akibat praktik-praktik predator bisnis perusahaan-perusahaan multinasional yang beroperasi di wilayah itu. ${ }^{3}$ Atas nama tuntutan kemakmuran masyarakat miskin, atau yang dalam bahasa Orde Baru, disebut sebagai pembangunan, hutan-hutan disobek, bukit-gunung dibelah, dan masyarakat setempat dibuang keluar dari tanahnya. Penghancuran alam-lingkungan membawa serta penghancuran masyarakat, dan penghilangan identitas kultural masyarakat setempat. Dalam konteks sekarang pun, kita melihat

\footnotetext{
Francis, Laudato Si', 139.

Anna Lowenhaupt, Friction: $A n$ Etnography of Global Connection, (New Jersey: Princeton University Press, 2005).
}

bahwa privatisasi wilayah-wilayah demi keuntungan ekonomi melalui kerja sama antara operator perusahaan besar maupun kecil dan dengan bantuan tekanan politis dan militer, telah mengakibatkan banyak komunitas masyarakat menjadi asing di tanahnya sendiri. ${ }^{4}$

Di sini, eksploitasi atas nama apa yang disebut sebagai kemajuan (progressive) dan kemakmuran (prosperity), diterima sebagai satu-satunya, untuk menyebutnya dalam kosakata Aristotelian, penggerak utama dan tolok ukur bagi bentuk-bentuk pembenaran (justification) terhadap semua tata kelola tatanan manusia yang lain. Sehubungan dengan itu, kemajuan teknis-saintifik ini dengan perspektifnya yang abstrak, menurut Edmund Husserl berada dibalik semua bentuk krisis peradaban modern, seperti krisis kemanusiaan dan krisis lingkungan hidup. Saintisme yang berawal dari Galileo Galilei dan Isaac Newton, tetapi memiliki muasalnya dalam pemikiran antik melihat manusia maupun alam sekadar sebagai objek yang bisa dikalkulasi dan dibentuk menurut kepentingan-kepentingan material-biologis kita. ${ }^{5}$ Dalam argumentasi bahwa penyelidikan dan kebenaran ilmiah selalu dan mesti bebas nilai (objektif-positivistik), sesuatu yang diringkus dalam kerangka saintifik-

4 Cf. Lowenhaupt, Friction, 21; Cf. Didimus Dedi Dhosa, "Land Acquisition, Peasant Exclusion, and People Resistance Advocacy at Bolok Industrial Area in Kupang, East Nusa Tenggara, Indonesia," Sodality: Journal Sosiologi Pedesaan, Vol. 7, No. 3 (2019), 167-181. doi: https://doi.org/10.22500/sodality.v7i3.27169

Edmund Husserl, The Crisis of European Science and Transcendental Phenomenology, trans. David Carr, (Evanston: Northwestern University Press, 1970). 
ilmiah dilepaskan dari hubungan intrinsiknya dengan realitas lain di luar dirinya. Pengetahuan dan nilai menjadi sesuatu yang bersifat oposisional. Di hadapan kepentingan ilmiah, suatu kepentingan yang melayani akumulasi ekonomi kapital, nilai menjadi sesuatu yang mengganggu atau menghambat.

Lebih dalam dari itu, menurut Henryk Skolimowski, ${ }^{6}$ argumentasi yang memisahkan antara pengetahuan dan nilai pada dasarnya berangkat dari pemahaman yang keliru mengenai hubungan antara apa yang ada atau apa itu (what it is) dan apa yang seharusnya (what it ought to be), dan bagaimana bentuk saling-hubung antara manusia dengan seluruh alam. Saintisme yang membentuk masyarakat modern sebagai masyarakat teknis cenderung untuk mengabaikan hubungan tak terpisahkan antara apa yang kita lakukan dengan mengapa kita melakukan apa yang kita lakukan, karena ideologi dualisme yang meringkus cara berpikir manusia. ${ }^{7}$

\footnotetext{
6 Henryk Skolimowski (4 Mei 1930-6 April 2018), seorang filsuf Polandia. Menyelesaikan studi teknik dan filsafat di Warsawa, kemudian pada tahun 1964 mendapatkan gelar doktor filsafatnya dari Universitas Oxford, di mana ia sempat mengajar sebelum memulai karir keprofesorannya di Universitas Southern California. Dari sana ia kemudian pindah mengajar di Universitas Michigan sampai masa pensiunnya. Bukubukunya seperti Eco-Philosophy (1981), Living Philosophy: Eco-Philosophy as a Tree of Life (1992), menempatkannya sebagai seorang pemikir terkemuka dalam kajian Filsafat Ekologi.

7 Henryk Skolimowski, "Eco-Ethics as the Foundation of Conservation," Environmentalist 4, (1984), 45. https://doi.org/10.1007/BF01907293. Dalam artikel ini Skolimowski menunjukkan perbedaan antara Etika Lingkungan (Environmental Ethics) dan Etika Ekologi (Ecological Ethics). Etika
}

Sehubungan dengan itu, artikel ini adalah suatu pembacaan programatik atas krisis ekologi dan lingkungan hidup dari sudut pandang fenomenologi. Pada bagian yang pertama, akan ditunjukkan bahwa krisis ini berakar dalam padangan dualistik. Sebagai kritik atas pandangan tersebut, akan ditunjukkan respon teoritik melalui eko-fenomenologi sebagai teori interdisipliner dalam bagian kedua, dilanjutkan dengan reformulasi ulang konsep logos (akal budi) dalam bagian ketiga artikel ini. Bagian keempat adalah refleksi dari perspektif fenomenologi atas ciptaan sebagai sebuah tabernakel, tempat menetap nama yang ilahi, dan akan ditutup dengan sebuah simpulan kecil.

\section{Krisis: Pembedaan sebagai pemisahan}

Satu daya vital yang merupakan forma fundamental pemikiran Barat sejak awal hingga kini, suatu kerangka tunggal yang mendasari seluruh perilaku eksploitatif terhadap alam dan kelompok marjinal adalah apa yang dikenal sebagai dualisme. ${ }^{8}$ Salah satu aspek dikotomis

lingkungan mengkhususkan perhatiannya pada masalah etika yang berhubungan dengan masalah manajemen yang sesuai atas sumbersumber alam dan seringkali diarahkan oleh model analisis biaya-manfaat (cost-benefit analysis), sedangkan etika ekologi menaruh perhatian pada soal relasi manusia dengan alam. Apa yang sering diabaikan dari etika lingkungan adalah pengakuan akan nilai-nilai intrinsik di mana penghormatan terhadap kehidupan adalah sesuatu yang utama.

8 Husserl, The Crisis, 60. Gagasan dalam bagian ini secara garis besar akan mengikuti alur penalaran yang dibangun oleh Nikos Nissiotis "Nature and Creation: A Comment on the Environmental Problem from a Philosophical and Theological Standpoint," dan John Panteleimon Manoussakis, "Physis and Ktisis: 
yang sangat kuat mengarahkan cara berpikir dan bertindak kita adalah pembedaan antara manusia dengan alam. Selain itu ada pula pembedaan antara akal-budi (reason) dan alam (nature) yang diartikulasi oleh para pemikir antik. Dari sana, sebagai suatu gagasan historis, ia berkembang dalam model formasi yang berbeda-beda dari pemikir yang berbeda-beda pula. Dualisme sebagai pakem onto-epistemologis ini, tidak berhenti hanya pada pembedaan antara manusia dengan alam. Ia bersifat melebar dan atau meluas cakupannya. Manusia juga terbagi menjadi yang beradab versus barbarik, kaya versus miskin.

Misalnya, dalam konteks kolonialisme gagasan dualistik ini melahirkan asumsi tentang terra nullius: dalam pencarian dunia-dunia baru, setiap wilayah atau tempat baru yang 'ditemukan', dianggap tak bertuan, sekali pun punya penghuni, dan diklaim sebagai milik penguasannya. Kita tahu bahwa setiap penemuan diikuti dengan tindakan penamaan dan pengklaiman atas wilayah bersangkutan. Penamaan dan pengklaiman dengan menggunakan bendera, pada dasarnya tidak terkait dengan komunio (relasi) tetapi terkait dengan imperium: penaklukan dan eksploitasi. Yang datang menyebut dirinya beradab, yang ditemui disebut barbar. Dari segi keagamaan tidak dapat disangkal bahwa ada sisi positifnya, bahwa orang yang di Timor misalnya, bisa menerima apa yang kita kenal sebagai Kabar Gembira (Injil). Tetapi

Two Different Ways of Thinking of the World." Keduanya terdapat dalam John Chryssavgis and Bruce V. Foltz, Toward an Ecology of Transfiguration, (New York: Fordham University Press, 2013). dari sisi politik-ekonomi, kita tidak dapat menyangkal realitas perbudakan yang menyertai apa yang disebut sebagai pencarian dunia baru. ${ }^{9}$

Dalam kerangka berpikir dualistik ini, perbedaan (difference) juga dimaknai sebagai pemisahan (separation) dan bahkan pada lini Heraklitean-Marxisme dilihat sebagai pertentangan (opposition) antara satu dengan yang lain, sebuah pertarungan yang terus-menerus untuk saling meniadakan demi menggapai kebenasan dan independensi. Kita lalu berpikir tentang manusia versus alam, akal budi versus pengalaman, pikiran versus tubuh, yang-rasional versus yangemosional, diri-sendiri versus orang-lain, yang-hidup versus yang-tak-hidup, penegasan versus negasi, yang-dipelajari versus yang-bawaan, beradab versus barbarik, orang kaya versus orang miskin, laki-laki versus perempuan, superior versus inferior. Oleh karena itu, yang disebut sebagai kemajuan dalam kerangka dualisme ini tidak lain perendahan yang berlangsung dan kumulatif domain superior atas yang inferior. ${ }^{10}$ Walau bervariasi namun, naturalisme ini menempatkan manusia sebagai pusat ukuran (homo mensura) berdasarkan kemampuan inteleknya, secara khusus pikiran rasionalnya.

Pada Platon, kita menemukan suatu pembedaan radikal antara dunia kasat mata, yakni dunia yang kita alami (indrawi) dengan suatu dunia tak-kasat mata, bidang yang melampaui yang

9 Gambaran-gambaran seperti itu dapat ditonton misalnya dalam film 1492: Conquest of Paradise (1992) arahan Ridley Scott tentang penemuan kepulauan Bahama oleh Columbus, atau The New World (2005) arahan Terrence Malick.

10 Cf. Vernon Pratt, Environment and Philosophy, (London: Routledge, 1999), 42. 
indrawi, tatanan ide-ide yang bersifat abadi. $^{11}$ Selain pembedaan di atas, Platon juga membuat pembedaan lain yakni dua kemampuan manusia untuk mengakses kenyataan di luar dirinya. Menurut Platon, indra-indralah yang memberi kita akses kepada dunia indrawi. Lalu pertanyaannya adalah bagaimana kita mengakses dunia gagasan-gagasan? Bagi Platon, jawabannya adalah melalui akal budi atau intelek kita. Namun, akses kita kepada dunia tersebut sangat terbatas dibanding akses kepada dunia pengalaman indrawi, dan akal budi kitalah yang menyingkapkan kepada kita sedikit dari apa yang dapat kita ketahui itu. Jadi dalam pemikiran Platon, kita menemukan dua jenis dualisme. Yang pertama, adalah pembedaan antara dunia pengalaman indrawi dengan dunia idea. Yang kedua adalah pembedaan antara persepsi indrawi dan akal budi. Nampak jelas bahwa, Platon menetapkan dua dunia yang berbeda dan nampaknya saling bertentangan. ${ }^{12}$

Walau terdapat pembedaan terhadap tatanan dunia, dalam bingkai landasan rasionalistik dan pengspritualan, para

11 Gagasan tentang teori bentuk-bentuk ini tersebar dalam beberapa karya antara lain Phaedo, Republic, Phaedrus. Lih. Plato, Complete Works, ed. John M. Cooper (Indiana: Hackett Publishing, 1997); Pratt, Environment and Philosophy,

12 Gagasan Platonik ini memang berakar dalam pandangan mistik yang menerima adanya tatanan dunia yang bersifat hirarkis, mulai dari dunia material yang kasat-mata sebagai dunia yang paling rendah menuju suatu dunia yang tertinggi dan tak-kasat mata dan abadi. Gagasan ini, secara spiritual tidak dapat disangkal, walau menjadi sesuatu yang dipertanyakan dalam alam pikir yang menerima materialitas sebagai satusatunya elemen penentu kebenaran tentang eksistensi sesuatu. pemikir antik Yunani seperti Platon, tetap berupaya menjaga keseimbangan pandangan antara yang rohaniah dan yang material dan menginspirasi penghormatan dan kekaguman terhadap ciptaan seluruhnya. Artinya, kontemplasi terhadap alam pada puncaknya yang tertinggi adalah kontemplasi tentang diri manusia dan Yang-Tak-Berhingga, yang mendasari seluruh keberadaan tersebut. Sehubungan dengan ini, tercakup di dalamnya prioritas nilai yang diberikan kepada hal-hal yang bersifat spiritual dalam perbandingan dengan yang material. Selanjutnya, filsafat Aristotelian, oleh pengandaian Platonisme dan upaya untuk menjauh dari interpretasi ekstrim yang diberikan oleh pandangan idealisme, mengupayakan suatu pandangan yang seimbang selama periode sesudahnya. Di sini, materi tidak sekadar sesuatu yang ada begitu saja.

Lebih dari itu, dalam perspektif Aristotelian, materi adalah elemen yang dalam komposisinya dengan forma memungkinkan sesuatu mampu bereksistensi, mampu berada menurut caranya yang tertentu dan unik. ${ }^{13}$ Realitas alamiah, segala sesuatu yang hadir dalam keberadaannya dibangun oleh sebentuk komposisi sejoli-filosofis yakni materi dan forma. Maka, materi adalah apa yang eksis sebagai sesuatu yang secara potensial bisa dibentuk lebih lanjut, yakni kemungkinan berada yang oleh esensinya hadir dalam bentukbentuk yang tertentu. Jadi ada sebuah korespondensi, koherensi dan kedekatan yang mencukupi serta suatu hubungan

13 Salah satu studi yang cukup komprehensif adalah buku C. D. C. Reeve, Substantial Knowledge: Aristotle's Metaphysics, (Indiana: Hackett Publishing, 2000). 
yang tak terpisahkan secara alamiah antara roh-intelek di satu pihak, dan kenyataan material dan objek-objek material di lain pihak, suatu hubungan melaluinya seluruh ilmu pengetahuan mendasarkan diri.

Sehubungan dengan itu, Aristoteles secara jelas membedakan antara apa yang dihasilkan oleh manusia, yakni techne, dan apa yang tidak bergantung pada manusia, yakni physei (realitas materi-alamiah). Konsep physei hanya masuk akal dalam skema materia, gerak, forma dan tujuan tertentu. Maka, physis ini, bagi Aristoteles bergantung pada techne. Tetapi, physis itu bukan ktisis (ciptaan). ${ }^{14}$ Dalam konsep penciptaan, manusia menempatkan dirinya dalam kesatuan secara tak terpisahkan dengan seluruh ciptaan. Ciptaan adalah manusia dan dunia yang dipikirkan secara bersama-sama, di mana dunia menjadi tempat (place) manusia. Namun, dalam filsafat yang terlalu antroposentrik, pertanyaan tentang diri sendiri (siapa $a k u$ ?) secara langsung menegasi dari lingkup kesadaran kita lokalitas subjek (di mana aku?). Tak heran bahwa kemudian, alam pikir kita dibentuk sedemikian sehingga ketika kita memikirkan tubuh kita misalnya, kita menyadarinya sebagai entitas yang melokalisir diri kita pada suatu tempat tertentu, dan melalui tubuh itulah seseorang terhubung dengan dunia. Maka pemahaman kita tentang dunia sebagai tempat pada akhirnya tidak lain pemahaman tentang subjek. Subjek menjadi pusat.

Inilah bentuk monisme antroporasionalistik yang memberi prioritas kepada hal-hal rohaniah dibanding yang 206. material. Akal budi lebih superior dibandingkan realitas material. Konsekuensinya alam dipandang melulu sebagai materi yang dapat dieksploitasi untuk melayani kemajuan material dan teknologis. $^{15}$ Dari segi epistemologis, kekeliruan kekeliruan dalam penyamaan antara kenyataan ektra-mental dengan materi, di mana oposisi atau perbedaan antara subjek dan objek diandaikan sama dengan oposisi atau pembedaan antara pikiran dan materi. Penyebab material dipandang murni sebagai penyebab primer. ${ }^{16}$ Realisme menjadi materialisme dalam Marxisme.

Persis di sinilah masalahnya. Determinasi teknologi atas pikiran manusia, atau dalam bahasa yang umum, determinasi pikiran objektif berdasarkan tertib ilmu-ilmu alam sangat menentukan cara pikir manusia ketika berhadapan dengan alam. Skolimowski secara tegas menyatakan bahwa:

Pengetahuan dan seluruh ilmu pengetahuan diubah menjadi instrumental; pengetahuan dan ilmu pengetahuan hanya melayani maksudmaksud pragmatis, seringkali sedemikian dalamnya-ke-dalam-bumi, dan pertama-tama digunakan untuk mengubah bumi sehingga dapat melayani masyarakat. Kemudian, setelah dua abad, ilmu pengetahuan mulai digunakan untuk memproduksi produkproduk plastik dan kehidupan plastik. Pada akhirnya, ia meringkus masyarakat yang menghubungkan dirinya dengan produk platik tertentu. ${ }^{17}$

\footnotetext{
15 Nissiotis "Nature and Creation," 194.

16 Cf. Gerald A. McCool, "Jacques Maritain: A Neo-Thomist Classic," The Journal of Religion, Vol. 58, No. 4 (October 1978), 380404.

17 Terdapat dalam Jan Szmyd, "Modern Eco-Philosophy and Phenomenology of Life on
} 
Berdasarkan kenyataan ini, Skolimowski menegaskan lebih lanjut bahwa ketika pikiran objektif ini mendominasi atau menentukan cara pikir manusia, terciptalah keluarga-keluarga atomistik, masyarakat atomistik, individu maupun komunitas yang teralienasi, dan lebih jauh dapat ditambahkan bahwa ia juga menempatkan alam sebagai sesuatu yang asing bagi manusia. ${ }^{18}$ Dengan lain perkataan, bisa dinyatakan bahwa sebagaimana sudah disinggung di atas bahwa semangat keilmiahan mengakibatkan subjek (manusia) dilihat sebagai suatu pengamat impersonal dan netral, demi menjamin objektivitas keilmiahan. Padahal dalam kenyataannya, atas nama objektivitas ilmiah itulah kita melihat bahwa bumi bergerak ke arah jurang kehancuran. ${ }^{19}$

Dengan demikian, berdasarkan ontologi yang reduktif itu, kepada kita diwariskan suatu model bernalar yang yakin bahwa apa yang disebut rasional itu tidak lain adalah yang dapat dihitung atau diukur menurut tata logika ilmu-ilmu nomologis, ilmu-ilmu yang berorientasi pada kontrol teknis. Husserl menunjukkan bahwa perkembangan itu membawa serta sebentuk penegasan tak langsung bahwa dunia dalam dirinya mesti menjadi dunia yang rasional dan manusia dalam dirinya tidak lain adalah

Human Positioning in the Cosmos: A.-T. Tymieniecka and Henryk Skolimowski in Comparison," Phenomenology and the Human Positioning in the Cosmos II: The Life-world, Nature, Earth, ed. Anna-Teresa Tymieniecka (Dordrecht: Springer, 2013), 10.

18 Henryk Skolimowski, Participatory Mind: A New Theory of Knowledge and of the Universe, (London: Pinguin Books, 1994), 149.

19 Cf. Haryatmoko, Dominasi Penuh Muslihat: Akar Kekerasan dan Diskriminasi, (Jakarta: Gramedia Pustaka Utama, 2010). murni tubuh yang mematerial. ${ }^{20}$ Namun, kalau kita membaca secara tepat pemikiran Platon yang dicap sebagai muasal pemikiran dualisme, kita akan menemukan bahwa ia tidak mendorong pembacanya untuk melihat yang material sebagai tidak bernilai, sebagaimana dilakukan oleh para idealis dari periode yang kemudian yang menekankan secara ekstrim dan penginterpretasian satu-sisi atas pemikiran Platon. Dalam Sophist, dia menulis bahwa "memisahkan sesuatu dari segala sesuatu lain, berarti menghancurkan secara total segala sesuatu yang ada untuk dinyatakan". ${ }^{21}$ Artinya, secara fenomenologis, Platon tidak melihat dunia di sekeliling atau dunia yang mengelilingi kita sekadar sebagai materialitas yang berhingga dan tertutup serta bertentangan tetapi sebagai horizon melaluinya semua fenomena indrawi itu menyingkapkan dirinya.

\section{Eko-fenomenologi}

Fenomenologi yang dimulai oleh Husserl lahir sebagai perlawanan terhadap naturalisme GalileianNewtonian yang memandang realitas alamiah, baik itu manusia maupun alam semata-mata dari sisi penyebaban (kausalitas). ${ }^{22}$ Perspektif ini dibentuk

\footnotetext{
20 Cf. Husserl, The Crisis, 61.

21 Plato, Sophist, 259e3-4.

22 Dalam filsafat ilmu pengetahuan,
} terdapat tiga makna berbeda tentang naturalisme. Pertama, bahwa sebuah keputusan moral dapat disimpulkan dari pernyataan-pernyataan faktual (kritik eksplanatif). Kedua, term ini dipakai untuk merujuk pada ilmu-ilmu sosial yang mengambil model penyelidikannya dari ilmuilmu alam. Ketiga, dalam penggunaan filosofisnya, term ini dipakai untuk mengkarakterisasi pandangan tentang kodrat manusia dan masyarakat yang tersituasi oleh lingkungan mereka. Pandangan Darwinian misalnya melihat manusia sebagai hewan 
oleh kecenderungan penaturalisasian segala sesuatu, di mana kesadaran juga dilihat sebagai suatu penyebab (efficient cause) dan dunia sebagai efek atau akibatnya. Kalau menyelidiki penyebab dalam suatu peristiwa misalnya akan berarti menjelaskan sebab munculnya peristiwa bersangkutan. Menjelaskan sebab munculnya berarti memastikan bahwa ada hubungan yang bersifat tetap antara sebab dan akibat yang terjadi. Kalau alam dimengerti dalam kerangka sebab-akibat, tingkat presisi dari ramalan akan suatu peristiwai yang akan terjadi di masa depan mendekati sempurna. Maksudnya, munculnya suatu peristiwa di masa depan dapat diramalkan dengan kepastian yang maksimal. Kalau sudah bisa diramalkan berarti bisa dikuasai, yakni dengan memanipulasi penyebab yang terdapat dalam peristiwa tersebut. Maka, dengan manipulasi alam atau proses-proses alam dapat dikendalikan dan bahkan dimanfaatkan untuk kepentingan manusia. Dengan demikian, dalam perkembangan lebih kemudian, tanpa sadar penyebaban (efficient causes) berubah rupa menjadi pengetahuan teknis-bagaimana (technical know-how). Ilmu menjadi teknik, dan pengetahuan berarti penguasaan (knowledge is power). ${ }^{23}$

mamalia yang telah mencapai tahap evolusi yang lebih maju. Dalam artikel ini, kalau disebut naturalisme, maka dimaksudkan dalam artinya yang kedua yakni terkait dengan ilmu-ilmu yang bersifat nomologis. Untuk pendalaman lebih lanjut, lihat Ian Craib and Ted Benton, Philosophy of Social Science: the Philosophical Foundation of Social Thought, $2^{\text {nd }}$ ed., (2011).

23 Cf. Jürgen Habermas, Knowledge and Human Interests, trans. Jeremy J. Shapiro (Boston: Beacon Press, 1971); Cf. Ignas Kleden, Sikap Ilmiah dan Kritik Kebudayaan, (Jakarta: LP3ES, 1987), 86-87.
Bagi Husserl, dunia dibuka atau diungkapkan dirinya melalui kesadaran, maka tidak mungkin kita mengetahui dunia tanpa kesadaran. Tetapi, kalau kesadaran dilihat sebagai bagian dari dunia, maka keterbukaan atau keterarahan dasariah dari kesadaran itu dinegasi atau disangkal seluruhnya. Naturalisme dalam arti inilah yang coba dilawan oleh Husserl, naturalisme bukan sebagai sesuatu yang mengkonstitusi kenyataan tetapi naturalisme sebagai yang mengkualifikasi kenyataan menurut tata tertib matematis. ${ }^{24}$ Kalau ia melawan naturalisme, itu tidak berarti ia melawan atau menyangkal alam (nature). Dalam salah satu bukunya yang terkenal, Husserl mendiskusikan gagasan tentang kodrat alamiah dalam arti yang umum, kemudian mendiskusikan hal-hal material, binatang, dan kodrat manusia, dan menempatkan semuanya itu dalam bidang kepribadian dan roh. ${ }^{25}$

Dengan mendiskusikan hal-hal tersebut, Husserl mengarahkan perhatian kita pada jalan melaluinya kita menghubungkan diri dengan tubuh sendiri, dengan orang lain dan dengan dunia yang melingkupi kita. Selain itu,

24 Cf. David Wood, "What is Phenomenology?" Eco-Phenomenology: Back to the Earth Itself, eds. Charles Brown and Ted Toadvine (Albany, NY: SUNY Press, 2003), 211-212.

25 Edmund Husserl, Ideas Pertaining to a Pure Phenomenology and to a Phenomenological Philosophy II, trans. Richard Rojcewicz and André Schuwer (Dordrecht: Kluwer Academic, 1989); Cf. Debika Saha, "Eco-Phenomenological Vision: Balancing the Harmony of the Earth," Eco-Phenomenology: Life, Human Life, Post-Human Life in the Harmony of the Cosmos, eds. William S. Smith, Jadwiga S. Smith, Daniela Verducci (Switzerland: Springer International, 2018), 187190. 
dapat kita ketahui bahwa bersamaan dengan karyanya tentang konstitusi sosial dan dunia kehidupan setiap pribadi, Husserl juga mendiskusikan dalam karyanya yang lain soal subjektivitas transendental. Hal ini dimaksudkan untuk menunjukkan bahwa untuk bisa mencapai level pemahaman yang maksimal dan menyeluruh tentang hal-hal yang mengkonstitusi dunia kehidupan objektif, kita perlu juga memahami secara tepat aspek kultural (alam maknawi) dan alamiah (alam pramaknawi) dari kenyataan. Fenomenologi menyediakan sebuah cakrawala yang terbuka bagi eksplorasi lebih dalam tentang hubungan kita dengan alam melampaui batasan-batasan disiplin ilmu yang ditentukan secara sempit. Bila disiplin-disiplin ilmu yang lain, umumnya membingkai hubungan kita dengan alam menurut hubungan penyebaban (kausalitas), maka fenomenologi membantu kita untuk membangun suatu bentuk hubungan intensionalitas dengan alam, suatu cara berada yang bersifat partisipatif.

Fenomenologi menunjukkan bahwa pemikiran Barat yang sangat kuat diwarnai paham dualisme tidak menunjukkan secara tepat pembedaan antara ruang (area tertentu - space) dan tempat, kompleks, ruang di mana kita menetap atau berada (place). Ruang (space) selalu bersifat abstrak, dan bersifat non-manusiawi, sedangkan tempat (place) berhubungan dengan pengalaman kita melibatkan diri dalam dunia (mendunia). Tempat dalam arti tertentu berhubungan dengan soal identitas dan berarti terkait dengan aspek sosial-budaya seseorang, sedangkan ruang adalah sesuatu yang abstrak dan selalu ditempatkan dalam konteks pragmatis. $^{26}$ Keterarahan alamiah manusia kepada dunia yang melingkupinya adalah menemukan dirinya di dalam dunia itu. Maka konsep pertama dunia adalah bahwa manusia ada di dalamnya. Pemahaman semacam ini menyingkapkan beberapa gambaran yang pasti tentang dunia sebagai sebuah wadah, sebagai suatu ruang yang merentang sebagai suatu panjang yang tak terhitung. Dunia dimengerti dalam tertib logika matematika. Dalam perspektif seperti ini, kita memahami dunia dalam term area tertentu (space). Maka ketika kita berpikir tentang dunia, umumnya yang kita maksudkan adalah segala sesuatu yang ada di luar sana atau yang-ada-disekeliling kita, orang lain dan sesuatu yang menyertai dan menopang rutinitas harian kita. Dunia adalah sesuatu yang berbeda, lain dari diri subjek yang sadar-diri, dunia adalah sesuatu yang tertutup dalam dirinya sendiri.

Seturut itu, dalam konteks ekophenomenologi, Anna-Teresa Tymieniecka $^{27}$ menegaskan bahwa

26 Manoussakis, "Physis and Ktisis," 204. Pembedaan lebih lanjut tentang space dan place, lihat penjelasan dalam Edward C. Relph, Place and Placeness, (London: Pion Limited, 1979) dan buku-buku dari Jeff Malpas seperti Place and Experience: A Philosophical Topography, (Cambridge: Cambridge University Press, 1999); The Place of Landscape: Concepts, Contexts, Studies, (Cambridge, MA: The MIT Press, 2011).

27 Anna-Teresa Tymieniecka (28 Februari 1923-7 Juni 2014), adalah filsuf PolandiaAmerika, fenomenolog, dan pendiri sekaligus presiden The World Phenomenologi Institute. Editor untuk serial buku Analecta Husserliana. Menyelesaikan studi filsafatnya di Universitas Jagiellonian di Krakow di bawah bimbingan Roman Ingarden. Memperoleh dua gelar doctor, masing-masing tentang dasar-dasar fenomenologi Hartmann dan Ingarden dari 
manusia bisa dipertimbangkan sebagai "kondisi manusia dalam kesatuan dengan segala sesuatu yang hidup" ${ }^{28}$ Artinya, manusia membuka dan menghasilkan dalam suatu kesalingan relasi kontributif dengan seluruh ciptaan. Pernyataan Tymieniecka memerlihatkan spirit eko-fenomenologi, yang menuntut sebentuk keterbukaan untuk bisa secara mendalam menukik ke dalam bentukbentuk 'kehadiran sensorial' dan memulihkan kembali martabat moral kemanusiaan melalui pengungkapan makna moral dari ciptaan. ${ }^{29}$ Dalam arti ini, dasar teoritis dari eko-fenomenologi adalah fenomenologi kondisi manusia dalam dunia alamiah dan dalam kosmos secara umum.

Ketika suatu kebenaran yang tak tergoyahkan dan dasar teoritis yang kuat dipersiapkan dengan tepat, maka kita mampu membangun lebih lanjut tiga disiplin teoritis di atas dasar tersebut sebagai komponen konkret ekofenomenologi. ${ }^{30}$ Yang pertama, seperti telah disebut, fenomenologi eksistensi manusia kontemporer dalam era teknologi dan dunia yang terglobalisasi oleh industr, dan hubungan lingkungan alamiah dengan dunia manusia yang diarahkan oleh teknologi. Kedua, sebuah studi aksiologis tentang relasi manusia dengan alam, yakni evaluasi fenomenologis atas hubungan manusia dengan dunia alamiah. Dan yang ketiga,

Universitas Freibourg serta Filsafat Perancis dan Literatur dari Universitas Sorbonne.

28 Terdapat dalam Saha, "EcoPhenomenological Vision," 187.

29 Saha, "Eco-Phenomenological Vision," 187-188.

30 Bence Peter Marosan, "The Primal Child of Nature - Towards a Systematic Theory of Eco-Phenomenology," Phenomenology and the Human Positioning in the Cosmos II, 119. sebuah penyelidikan etis yang berorientasi praktis tentang bagaimana seharusnya manusia menghubungkan dirinya dengan dunia alamiah. Maksudnya, bagaimana ekofenomenologi memiliki efek positif terhadap kenyataan sosial ekstrasaintifik dan turut memengaruhi hubungan dengan pertanyaan-pertanyaan dan problem-problem lingkungan, pada lingkup politik.

Di tempat lain, Charles Brown dan Ted Toadvine dalam pengantar buku EcoPhenomenology menulis bahwa:

Titik simpul antara pemikiran ekologis dengan fenomenologi, momentum yang saling menggerakkan satu sama lain, melahirkan suatu penyelidikan lintas disipliner yang baru: eko-fenomenologi. Eko-fenomenologi dibangun di atas sebuah klaim rangkap: pertama, bahwa suatu penjelasan yang memadai atas situasi ekologis kita membutuhkan metode dan wawasan dari fenomenologi; dan yang kedua, bahwa fenomenologi, didorong oleh momentumnya sendiri, menjadi suatu filsafat ekologi, yakni studi tentang hubungan timbal-balik antara organisme dan dunia dalam dimensi-dimensi metafisis dan aksiologisnya. ${ }^{31}$

Dengan lain perkataan, ekofenomenologi memercik keluar dari celah dualisme konseptual antara kultur dan alam, antara tindakan dan pikiran, antara techne dan sebuah etos yang baruberhadapan dengan dunia, antara yang superior dan yang inferior. Di

31 Charles Brown and Ted Toadvine, "Eco-Phenomenology: An Introduction," EcoPhenomenology: Back to the Earth Itself, eds Charles Brown and Ted Toadvine (Albany, NY: SUNY Press, 2003), xii-xiii. 
tempat lain David Wood menunjukkan bahwa eko-fenomenologi sebagai disiplin baru, turut ambil bagian dalam upaya mengatasi pandangan-pandangan reduktif dari naturalisme ilmu pengetahuan. Caranya dengan mengintegrasikan intensionalitas pengetahuan manusia dengan keberadaan yang menubuh (embodiment existence) dan dengan dunia. Kemenubuhan intensionalitas dan hubungan esensial menurut kebutuhankebutuhan dan hasrat-hasrat kita menutup jurang fenomenologi dan naturalisme, dan menghantar kita pada proses penaturalisasian atau detransendentalisasi kesadaran melalui perluasan afeksi atau empati kita dengan alam-lingkungan yang telah tereifikasi. ${ }^{32}$ Dengan kata lain, eko-fenomenologi mencoba mendorong akal budi untuk bergerak keluar dari batasan-batasan saintisme, memerluas horizon pemahaman dari yang bersifat satu arah menjadi bersifat spiral. ${ }^{33}$

Brown dan Toadvine mencatat bahwa dari Wood, kita bisa menemukan beberapa poin penting. ${ }^{34}$ Salah satunya, Wood menunjukkan bahwa naturalisme membuat manusia memandang lingkungan alamiah sebagai sesuatu yang asing dan karena itu perlu penaklukan. Dalam naturalisme, lingkungan alamiah direduksi pada kategori-kategori yang murni ekstensional. Maka eko-fenomenologi mencoba untuk menjauh dari kategorikategori tersebut, walau tidak bisa menyangkal bahwa eko-fenomenologi juga tetap bergantung pada dunia

\footnotetext{
32 Wood, "What is Phenomenology?" 231.

33 Skolimowski, Participatory Mind, 80.

34 Brown and Toadvine, "EcoPhenomenology: An Introduction,” xviii-xix.
}

alamiah sebagai titik tolak refleksinya. Sejalan dengan Tymieniecka, Wood menegaskan bahwa apa yang diupayakan melalui eko-fenomenologi adalah suatu rasionalitas yang berjumpa dan masuk dalam dialog dengan nilai-nilai yang ditangkap melalui pengalaman langsung, manusia, hal-hal non-manusia dalam dunia yang dialami. Rasionalitas yang tepat adalah rasionalitas yang sejauh mungkin mengambil jarak dari akal budi instrumental atau objektivitas ilmu pengetahuan, sebaliknya mengejar phronēsis dan kehidupan yang baik bagi kemanusiaan dan bumi ini. Hanya melalui suatu pembalikan (kehre) rasionalitas melalui konseptualisasi ulang tempat dan peran kita dalam alam, kita mampu menghadapi masalah jarak ketidakterhubungan kita dengan diri sendiri dan dengan alam. ${ }^{35}$ Dibahasakan dari arah yang berbeda, berarti rasionalitas yang coba dibangun adalah rasionalitas yang tidak menempatkan dirinya dalam posisi rivalitas dengan alam, tetapi rasionalitas yang mengambil bagian dalam keseluruhan konstelasi realitas.

\section{Logos partisipatif}

Setelah berjalan sejauh ini, semakin gamblang bahwa kondisi manusia saat ini terjebak ke dalam suatu naturalisme yang menghancurkan. Husserl melalui fenomenologinya dan dalam konteks artikel ini, eko-fenomenologi menunjukkan bahwa segala bentuk krisis yang terjadi akibat dominasi ilmu-ilmu nomologis, tidak berhubungan dengan krisis dalam ilmu pengetahuan, tetapi

\footnotetext{
35 Brown and Toadvine, "EcoPhenomenology: An Introduction," xx.
} 
krisis sebagai ilmu pengetahuan. ${ }^{36}$ Manusia berada dalam suatu dunia yang terindustrialisasi dan terteknologisasi. Dalam konteks masyarakat Indonesia umumnya, dan NTT khususnya yang dicap sebagai wilayah miskin menurut kategori-kategori kemajuan kapitalisme global, dan berada dalam ruang ketidakjelasan batas antara modernitas dan tradisionalitas kehancuran itu seringkali berlangsung atas nama penyejahteraan masyarakatnya. Eksistensi manusia ini, caranya menghadapi alam atau bereaksi terhadap alam dan lingkungan sangat terdeterminasi oleh dunia yang terglobalisasi secara ekonomi dan teknologi planet. Maka, pada era ini, apa yang kita sebut sebagai lingkungan alamiah manusia tidak lain sebentuk hubungan dengan alam yang ditentukan dan diarahkan menurut nalar teknologi. Manusia dalam antropologi kemajuan ini adalah a tool making animal. ${ }^{37}$

Dari sana kita bisa membaca bahwa rasionalitas yang dideterminasi oleh naturalisme (ilmu-ilmu nomologis) adalah rasionalitas yang berjarak dari kenyataan, rasionalitas yang terasing, rasionalitas yang ahistoris, dan bukan rasionalitas yang bersifat historis (tidak dalam pengertian dalam paham historisisme), yang melibatkan dirinya dalam dunia pengalaman konkret dan lingkungan alamiah. ${ }^{38}$ Rasionalitas ini

36 Cf. Habermas, Knowledge and Human Interests, 302.

37 Habermas, Knowledge and Human Interests, 28.

38 Persoalan mengenai historis atau ahistoris merujuk kepada problem hubungan antara

kemengaliran realitas (Sein) dan kesadaran manusia berhadapan dengan kemengaliran realitas tidak beroperasi di dalam kerangka keutuhan dan keterhubungan, tetapi beroperasi dalam batas-batas yang fragmentaris dan mengoyak, padahal dalam kehadiran operasionalnya, dinamika rasio (akal budi) - dalam ungkapan Maurice Merleau-Ponty berciri khiasmik. Artinya, akal budi bergerak di antara realitas kasat mata dan realitas tak-kasat mata, di antara yang imanen dan material. Karena manusia adalah ada berjaringan (networks being), maka akal budinya juga selalu berada dalam suatu keterjalinan dengan realitas kasat mata maupun tak-kasat mata. Saintisme memang mengakui keterjalinan itu, tapi ditempatkan dalam kerangka penyebaban (kausalitas) dan bukan intensionalitas. Sebelum melanjutkan ke soal intensionalitas, saya perlu

bersangkutan (Bewußtsein). Dalam ilmu pengetahuan, keduanya selalu dapat dipakai secara

bersama-sama. Misalnya, seseorang bisa menjelaskan sebab-sebab suatu perang dapat terjadi

(ahistoris), tetapi ia tidak menjelaskan mengapa perang itu terjadi di tempat tertentu dan pada waktu tertentu (historis). Hukum-hukum ilmu pengetahuan selalu bersifat ahistoris. Dalam filsafat, kita dapat menyatakan bahwa proyek filsafat sejarah spekulatif Hegel adalah sebuah filsafat yang ahistoris atau imanen, karena ia berasumsi bahwa secara formal dan material sejarah ditentukan oleh akal budi. Pada epistemologi Kant misalnya, Sein yang sebenarnya

adalah kategori-kategori pikiran, sedangkan realitas atau keadaan ada sejauh disesuaikan dengan kategori-kategori tersebut. Pada materialisme Marx, Sein yang sebenarnya adalah perkembangan sosial ekonomi. Pada dekonstruksi Derrida, Sein yang sebenarnya adalah

differánce, rangkaian penanda (signifier) tanpa yang ditandakan (signified). 
memerjelas apa yang dimaksudkan dengan logos di sini.

Dalam filsafat antik, $\operatorname{logos}(\lambda$ ó $\gamma \mathrm{o} \varsigma)$ memiliki hubungan dengan episteme ( $\dot{\pi} \pi \sigma \tau \eta \dot{\mu \eta})$. Logos sebagai term teknis dimulai oleh Heraklitos. Bagi pemikir antik dari Efesus ini, logos adalah "prinsip tatanan dan pengetahuan".39 Sebagai prinsip, logos meresapi (permeate)segala sesuatu, menjadi daya atau energi yang menggerakkan dan menentukan arah dari sesuatu ke depan, tetapi banyak yang tidak mengetahui dan menyadari kehadirannya, seperti seorang yang tidur sambil berjalan. Selain sebagai prinsip, logos juga berarti akal budi, penalaran akal budi, kemampuan akal budi. Dalam arti yang lain lagi, logos berarti ukuran, relasi. ${ }^{40}$

39 Daniel W. Graham, "Heraclitus," The Cambridge Dictionary of Philosophy, $2^{\text {nd }}$ edition, ed. Robert Audi, (Cambridge: Cambridge University Press, 1999), 376.

40 Roger Crisp, "Logos," The Cambridge Dictionary of Philosophy, 518. Penjelasan rinci tentang prinsip (arche) dapat dilihat dalam Giorgio Agamben, Creation and Anarchy: The Work of Art and the Religion of Capitalism, trans. Adam Kotsko (Stanford, CA: Stanford University Press, 2019), ch. 4. Kemudian, pada Philo dari Alexandria, logos sebagai satu term tunggal dengan beberapa makna ini dibagi menjadi dua logoi, yakni sebagai logos endiathetos dan logos prophorikos. Meski dihubungkan dengan Philo tetapi sudah diformulasi sebagai term teknis oleh para filsuf stoisis. Secara sederhana, kedua istilah ini digunakan untuk menunjukkan perbedaan dalam logos sebagai kata dan pembicaraan: logos internal (logos endiathetos) yang merujuk kepada dimensi imanen dari akal budi (noetis), dan logos yang terucap. Kedua logoi ini saling berkaitan karena logos yang terucap ibarat kendaraan yang menghantar ke luar apa yang dihasilkan oleh logos internal. Lihat penjelasan dalam Adam Kamesar, "The Logos Endiathetos and the Logos Prophorikos in Allegorical Interpretation: Philo and the D-Scholia to the
Di tempat lain, Heidegger mencatat bahwa episteme dari kata epistasthai yang berarti menempatkan seseorang di depan sesuatu, berdiri di depan sesuatu dalam cara melaluinya dan untuk maksud itu, sesuatu menunjukkan dirinya. Berdiri di depan sesuatu berarti membiarkan sesuatu untuk menunjukkan dirinya kepada orang lain, untuk dapat berdiri di depan yang menunjukkan dirinya dalam cara menurut apanya (esensi), dan bagaimana sesuatu itu menunjukkan dirinya sebagai dirinya. Dari sini kemudian datang pengartian epistasthai sebagai 'memahami sesuatu' (the understanding of something). ${ }^{41}$ Dalam telisiknya, atas fragmen-fragmen Heraklitos, Heidegger kemudian menyimpulkan bahwa pada pemikiran antik yang disebut logis itu tidak lain

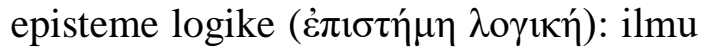
tentang logos dan apa yang berkaitan dengan logos.

Pada perkembangan awal logika di Yunani antik, kata episteme memiliki makna atau dekat dihubungkan dengan tekne $(\tau \dot{\varepsilon} \chi \nu \eta)$ yang berarti 'pengetahuan tentang sesuatu'; (knowledge of something), maka kemudian di bawah pengaruh cara pikir dan teknologi modern, makna episteme diperkuat hanya pada soal ilmu pengetahuan teknis sebagaimana dicatat oleh Husserl dan Habermas, karena ilmu pengetahuan pun dimengerti semata-mata pada soal teknik dan penguasaan. ${ }^{42}$ Dari pendalaman yang dilakukan oleh Heidegger, serta kandungan makna dari term tersebut,

Iliad," Greek, Roman, and Byzantine Studies, 44 (2004), 163-181.

41 Martin Heidegger, Heraclitus, trans. Julia G. Assaiante and S. Montgomery Ewegen (London: Bloomsbury, 2018), 152.

42 Heidegger, Heraclitus, 162; Habermas, Knowledge and Human Interests, $301 \mathrm{ff}$. 
bisa ditegaskan di seini bahwa logos tidak lain prinsip penalaran yang bersifat relasional. Tentang ini Tymieniecka menjelaskan bahwa:

Ketika kita ingin "memahami sesuatu", secara berlanjut kita fokus pada keperbedaan (sesuatu itu) pada level manifestasi fenomenal dari hal-hal lain, ada-ada, peristiwa-peristiwa, etc., dan untuk mengupas (exfoliate) kodratnya dalam term-term keterlibatannya yang teramat rumit dengan semua itu. Kita melakukan dengan menyelidiki keterlibatan tersebut melalui lingkaran yang berbeda-beda: modus-modus pembedaan-genetik, komposibilitas dinamis-genetik, peliputan yang banyak dan pola-pola komposibilitas yang disingularisasikan. Kita kemudian, dalam penelisikan kita menuju sistem universal kehidupan dan menuju relevansi pola-polanya yang mungkin ... Tetapi kita tidak dapat mengakhiri pengupasan alasan-alasan rasional untuk "sesuatu" tanpa melacak perkembangan genetik menurut relevansinya dalam tatanan ketertiban kosmos, dinamika hukum-hukumnya, proses-prosesnya.... Hanya di dalam keseluruhan skema "akal budi" kita mampu menggapai pengupasan penuh atas "sesuatu": pengupasannya bukan dalam ada tetapi dalam "apa artinya menjadi", pengupasan dalam logosnya. Secara singkat, untuk segala sesuatu, apa pun yang mau dipahami, ia harus dikupas dalam totalitas (All)". ${ }^{43}$

Dari pernyataan ini, Tymieniecka hendak menegaskan bahwa dengan memahami sesuatu, terutama realitas

43 Anna-Teresa Tymieniecka, Impetus and Equipose in the Life-Strategies of Reason, (Dordrecht: Kluwer Academic, 2000), 34. dalam totalitas dirinya, kita diantar untuk sampai pada apa yang disebut sebagai ontopoiesis kehidupan: bahwa setiap hal punya modus perkembangan dirinya (self-individualizing progress) sendiri yang mendahului kriteria-kriteria pikiran kita. Diri sendiri (self) karena berlangsung dan berawal dari dalam sesuatu itu, tetapi bergerak menuju depan. ${ }^{44}$ Onto merujuk pada permulaan (firstness) dari proses kehidupan dengan respek terhadap skala formasi eksistensinya. 'Sebelum' skema onto ini diartikulasi, kita tidak mampu menempatkan sesuatu di dalam skemaskema pikiran kita sendiri. Maka ontojuga berarti karakter konstitutif dan universal dari apa pun untuk bisa berada dalam bentuk 'objektif' yang layak bagi realitas manusia. ${ }^{45}$

Oleh sebab itu, Tymieniecka secara tegas menyatakan bahwa logos adalah prinsip kehidupan itu sendiri yang menggerakkan sekaligus menyeimbangkan dan merupakan prinsip imanen dari logos itu sendiri. Logos adalah logos segala logos, dan logos manusia hanyalah salah satu dari sekian banyak logos dalam tertib kosmos ini. Logos ini mewahyukan dirinya melalui kehidupan. Kalau demikian, pada dasarnya logos bersifat relasional atau dalam bahasa Tymieniecka, logos yang beroperasi secara sosial. ${ }^{46}$ Dan relasionalitas inilah, hemat saya mengkonstitusi karakter intensionalitas dari akal budi dan kesadaran. ${ }^{47}$

44 Tymieniecka, Impetus and Equipose in the Life-Strategies of Reason, 628.

45 Tymieniecka, Impetus and Equipose in the Life-Strategies of Reason, 629.

46 Tymieniecka, Impetus and Equipose in the Life-Strategies of Reason, 338.

47 Cf. Tymieniecka, Impetus and Equipose in the Life-Strategies of Reason, 37-39. 
Intensionalitas adalah karakter utama akal budi, dan intensionalitas inilah yang memungkinkan akal budi mengambil bagian dalam tertib semesta. Intensionalitas sebagai bentuk keterarahan kepada realitas di luar akal budi memungkinkan akal budi menjadi historis, masuk ke dalam kenyataan. Inilah yang saya disebut sebagai logos (akal budi, pikiran) partisipatif, dan akal budi dalam eko-fenomenologi adalah akal budi partisipatif, akal budi yang tidak melihat dan menilai realitas dari suatu jarak yang tak terjembatani dengan kenyataan, pikiran yang tidak hanya tunduk kepada tujuan pemenuhan kebutuhan material-ekonomis yang menghancurkan (semata-mata fungsional), tetapi akal budi yang dapat terpana di hadapan realitas dan menghadapi realitas sebagai bagian dari dirinya. Akal budi yang partisipatif adalah "ekspresi rasional dari kekaguman menetap". ${ }^{48}$ Dalam kekaguman itu, dengan penuh belaskasih kita masuk ke dalam hubungan dengan kenyataan, orang lain dan lingkungan alamiah. Melalui pikiran yang partisipatif, kita masuk ke dalam keluasan rahasia semesta, yang menyingkapkan dirinya kepada kita hanya jika kita memiliki cukup kekuatan, empati dan imajinasi.

Akal budi partisipatif tidak menolak pemikiran objektif, tetapi mentransendensinya dalam upaya menggapai menggapai keutuhan sumber

48 Skolimowski, Participatory Mind, 174. Disini, kekaguman adalah terjemahan untuk kata magic dari Skolimowski, sedangkan Tymieniecka memakai kata wonderment, untuk menegaskan bahwa kita dipenjarakan oleh kekaguman atau keterpanaan tersebut. Lih. Tymieniecka, Impetus and Equipose in the LifeStrategies of Reason, 38. dari rasionalitas yang tak terukur tersebut, di mana kehidupan itu sendiri meminta sebuah gerak maju yang berkesinambungan. Dengan kata lain, akal budi partisipatif adalah akal budi yang masuk ke dalam kondisi dari kehidupan itu sendiri, akal budi yang dalam sikapnya terbuka kepada dunia, dan memanifestasikan dirinya sebagai ko-founder dan co-produser rangkaian kemenjadian ideal yang berlangsung dalam proses-proses kosmik dan pada saat yang sama dengan diri sendiri. Kehidupan ini bukanlah duniakehidupan yang telah diproyeksikan dan diramalkan menurut tertib ilmu pengetahuan teknis, tetapi kondisi manusia yang mencakup keutamaan yang memampukan manusia membuka dirinya bersama dengan duniakehidupan sebagai sumber proliferasi. ${ }^{49}$ Di sini, logos partisipatif sebagai prinsip kehidupan memanifestasikan dirinya dalam penampakan segala sesuatu, kosmos, dunia, alam, kehidupan, karya roh manusia. Jadi, kita hidup dalam jaringan tersebut, mencakup berbagai level ruang inter-relevan, dan saling menggerakkan satu sama lain menuju kepenuhannya.

\section{Tabernakel semesta}

Dalam bahasa Skolimowski, akal budi yang partisipatif bersifat ko-kreatif. Daya ko-kreatif dari akal budi menandakan sebuah pencarian kreatif atas kehidupan kita sendiri yang diresapi dengan perilaku hormat. Daya ini juga menandakan upaya kita untuk menyembuhkan bumi, dan secara umum

49 Anna-Teresa Tymieniecka, The Phenomenology of Man and of the Human Condition II, (Dordrecht: Kluwer Academic Publishers, 1986), 7. 
menolong semesta dalam prosesnya untuk terus berlanjut (becoming). ${ }^{50}$ Memang, Tymieniecka menunjukkan bahwa akal budi sebagai prinsip permulaan dalam percikannya bersifat konstruktif dan destruktif. Namun, destruktif di sini dimaksudkan dalam kaitannya dengan karakter utama akal budi sebagai yang menggerakkan dan menyeimbangkan, logos sebagai arche. Maka destruktif dalam Tymieniecka tidak dalam makna penghancuran yang diakibatkan oleh pekerjaan tangan manusia, tetapi destruktif dalam konteks sebagaimana dimaksudkan oleh Skolimowski. Dalam konteks ini, pernyataan Brian Swimme patut diperhatikan:

Kita harus merangkul dan menghargai mimpi kita tentang bumi. Dengan imajinasi, kita menciptakan sebuah periode pembangunan kembali, di mana interkomunio seluruh spesies akan memandu aktivitas-aktivitas kehidupan kita. Kita mesti sampai pada pemahaman bahwa mimpi-mimpi kita ini tidak semata-mata berasal dari otak kita. Kita adalah ruang bagi mimpi-mimpi bumi. Kita adalah imajinasi bumi, bahwa bidang yang berharga di mana visi-visi dan harapan-harapan ditata dapat berbicara dengan sebuah kesadaran pembedaan bukan kehadiran yang lain dalam sistem bumi. Kita adalah pikiran dan hati bumi, hanya sejauh kita memampukan bumi untuk menata aktivitasnya melalui kesadaran refleksidiri. Inilah takdir terbesar kita: membiarkan bumi menata dirinya melalui cara yang baru, dalam sebuah

50 Skolimowski, Participatory Mind, 175. cara yang tidak mungkin melalui jutaan tahun yang mendahului kemanusiaan. ${ }^{51}$

Sehubungan dengan itu, Skolimowski menulis bahwa "dunia bukan mesin tetapi suaka (sanctuary) perlindungan yang sangat mengagumkan". ${ }^{52}$ Kebanyakan pembacanya mengartikan sanctuary yang dipakainya sebagai "suaka" atau "tempat". Di sini, saya ingin mengartikannya sebagai suatu tabernakel yang merepresentasikan suatu transendensi, sebagai wajah tampak dari wajah tak-tampak Yang-Ilahi. Dalam arti ini, seseorang yang terendam-dalamdunia (immersion-in-world) pada dasarnya sedang membangun komunio dengan dunia. Dalam hubungan intensionalitas yang semacam itu, alam semesta yang melingkupinya bukanlah koleksi sejumlah besar objek, tetapi sebuah komunio inter-subjek.

Berpikir secara baik berarti turut mencipta dengan semesta. Berpikir secara benar berarti mengambil bagian secara konstruktif dalam kebaikan organisme hidup. Berpikir partisipatif berarti masuk dalam sebuah hubungan cinta dengan diri sendiri dengan mengangkat serta mengembangkan semesta menuju arah yang lebih baik. berpikir secara baik berarti bahwa integritas dan validitas pikiran kita sangat ditentukan oleh kemampuan untuk mengintegrasikan nilai-nilai ke dalam pemikiran, dan sebaliknya juga kapasitas kita untuk mengintegrasikan pikiran analitis ke dalam bingkai nilainilai yang berkelanjutan. ${ }^{53}$ Dalam arti

51 Brian Swimme dalam Skolimowski, Participatory Mind, 175.

${ }^{52} \mathrm{http}: / /$ ecoconscience.blogspot.com/2011/06/ world-is-sanctuary-henryk-skolimowski.html

53 Skolimowski, "Eco-Ethics as the Foundation of Conservation," 45. 
ini, akal budi mesti mendayagunakan kemampuannya untuk tidak terjebak hanya pada bidang fisik dari persoalan ekologis dan lingkungan. Maksudnya, akal budi dapat bergerak menuju tingkatan yang lebih tinggi lagi. Thomas Berry dalam salah satu tulisannya menulis bahwa kita akan kehilangan jiwa kita jika kita kehilangan pengalaman mengenai hutan, kupu-kupu yang beterbangan, kicauan burungburung, jika kita tidak dapat melihat bintang-bintang pada malam hari. Menurutnya Yang-Ilahi berkomunikasi dengan kita pertama-tama melalui bahasa dunia alamiah, maka kalau kita tidak lagi mendengarkan dunia alamiah, sama artinya dengan kita tidak lagi mendengarkan suara Yang-Ilahi.

Sehubungan dengan itu, dunia alamiah tidak pernah semata-mata hanya hal-hal fisik yang bisa dieksploitasi. Fenomenologi, dan terutama ekofenomenologi menolong kita untuk melihat dunia alamiah sebagai fenomena yang melimpah, yang menunjuk kepada suatu keberadaan yang tak-kasat mata, yakni Sang Dasariah (das Grund). Apa yang kasat-mata sebenarnya merupakan tempat berdiam yang tak-kasat-mata. Dalam arti ini seluruh tatanan ciptaan adalah hal utama dan pewahyuan yang sempurna tentang Yang-Ilahi. Untuk itu bisa dikatakan bahwa secara mistikfenomenologis, inkarnasi yang pertama sudah berawal dalam moment yang dalam tatanan ilmiah disebut sebagai dentuman besar: ini saat di mana YangIlahi secara aktual memutuskan untuk mematerialisasi dan mengekspose siapa itu Yang-Ilahi. Maka menyebut ciptaan mengindikasikan bahwa bukan manusia satu-satunya tempat pewahyuan, tetapi seluruh hal dalam dunia menjadi tempat berdiam namaNya [cf. "namaKu akan tinggal di sana" (1 Raj 8:29)]. Hal-hal fisik itu merupakan ikon (eikon), tempat berdiam dari yang tak-kasat mata.

\section{Kesimpulan}

Manusia zaman ini sudah mencapai suatu kemajuan yang tanpa tanding berkat kemajuan dalam ilmu pengetahuan. Keberhasilan itu dicapai antara lain karena akal budi kita mampu mengambil jarak dari realitas dan melihat dirinya (akal budi itu sendiri) sebagai suatu realitas yang berbeda dengan alam, akal budi sebagai sebab dan alam adalah akibat. Bahkan seiring kemajuan yang tanpa tanding dari teknologi berkat ilmu pengetahuan, telah mengubah struktur berpikir dan bertindak manusia berhadapan dengan alam. Oleh kemajuan itu pula, ruang dan waktu seolah meluruh, menghilangkan jarak dan waktu interaksi. Namun, kita tahu bahwa kemajuan itu sendiri memiliki akibat buruk yang tak kalah bandingnya dengan kemajuan yang dijanjikan olehnya. Akibat-akibat itu bisa kita rasakan melalui berbagai krisis yang terjadi, terutama dalam krisis ekologi dan lingkungan kita.

Berhadapan dengan situasi seperti itu, lahir kesadaran baru bahwa manusia harus memeriksa kembali asumsi-asumsi mendasar yang memberi justifikasi rasional atas semua bentuk kemajuan sekaligus krisis yang terjadi. Di sini, eko-fenomenologi, sebagai suatu disiplin baru menawarkan suatu model berpikir yang dilupakan sepanjang sejarah perkembangan ilmu pengetahuan modern. Cara berpikir itu adalah cara berpikir relasional, yang membawa kembali kesadaran manusia bahwa realitas mesti ditempatkan kembali pada posisinya yang tepat: akal budi mesti 
kembali kepada semesta itu sendiri. Dengan kembali kepada kenyataan itu sendiri, terbit fajar kesadaran baru bahwa alam sedapat mungkin dihadapi bukan sebagai sesuatu yang asing atau yang bermasalah dan perlu diselesaikan, melainkan sebagai bagian dari tertib semesta, di mana manusia menjadi bagian dari alam itu sendiri. Kesadaran itu malah mampu membawa manusia kembali pada tingkatan yang lebih tinggi, di mana disadari bahwa dibalik realitas yang kasat mata itu, berdiam realitas tak-kasat mata, realitas dasariah, logos semesta yang mendasari dan mengarahkan jalannya semesta. Apa yang menurut Weber disebut sebagai hilangnya daya magis alam akibat perkembangan ilmu pengetahuan justru memercik keluar dan menerangi kesadaran manusia ketika ia menghadapi alam bukan sebagai objek tetapi sebagai subjek.

\section{Daftar referensi}

Agamben, Giorgio. Creation and Anarchy: The Work of Art and the Religion of Capitalism. Trans. Adam Kotsko. Stanford, CA: Stanford University Press, 2019.

Brown, Charles and Ted Toadvine. "Eco-Phenomenology: An Introduction." Eco-Phenomenology: Back to the Earth Itself. Eds. Charles

Brown and Ted Toadvine. Albany, NY: SUNY Press, 2003. Craib, Ian and Ted Benton. Philosophy of Social Science: The Philosophical Foundation of Social Thought.Second edition. London: Macmillan, 2011.

Crisp, Roger. "Logos." The Cambridge Dictionary of Philosophy.
Second edition. Ed. Robert Audi. Cambridge: Cambridge University Press, 1999.

Dhosa, Didimus Dedi. "Land Acquisition, Peasant Exclusion, and People Resistance Advocacy at Bolok Industrial Area in Kupang, East Nusa Tenggara, Indonesia." Sodality: Journal Sosiologi Pedesaan, Vol. 7, No. 3 (2019): 167-181. doi: https://doi.org/10.22500/sodality.v7i3.27 169 http://www.vatican.va/content/francesco/ en/encyclicals/documents/papafrancesco_20150524_enciclica-laudatosi.html.

Graham, Daniel W. "Heraclitus."

The Cambridge Dictionary of Philosophy. Second edition. Ed. Robert Audi. Cambridge: Cambridge University Press, 1999.

Habermas, Jürgen. Knowledge and Human Interests. Trans. Jeremy J. Shapiro. Boston: Beacon Press, 1971.

Haryatmoko. Dominasi Penuh Muslihat: Akar Kekerasan dan Diskriminasi. Jakarta: Gramedia Pustaka Utama, 2010.

Heidegger, Martin. Heraclitus. Trans. Julia G. Assaiante and S. Montgomery Ewegen. London: Bloomsbury, 2018.

http://ecoconscience.blogspot.co m/2011/06/world-is-sanctuary-henrykskolimowski.html

Husserl, Edmund. Ideas Pertaining to a Pure Phenomenology and to a Phenomenological Philosophy II. Trans.

Richard Rojcewicz and André Schuwer. Dordrecht: Kluwer Academic, 1989. 
Husserl, Edmund. The Crisis of European Science and Transcendental Phenomenology. Trans. David Carr.

Evanston: Northwestern University Press, 1970.

Kamesar, Adam. "The Logos Endiathetos and the Logos Prophorikos in Allegorical Interpretation: Philo and the D-Scholia to the Iliad. " Greek, Roman, and Byzantine Studies, 44 (2004): 163-181.

Kleden, Ignas. Sikap Ilmiah dan Kritik Kebudayaan. Jakarta: LP3ES, 1987.

Lowenhaupt, Anna. Friction: An Etnography of Global Connection. New Jersey: Princeton University Press, 2005.

Malpas, Jeff. Place and Experience: $\quad A \quad$ Philosophical Topography. Cambridge: Cambridge University Press, 1999.

Malpas, Jeff. The Place of Landscape: Concepts, Contexts, Studies. Cambridge, MA: The MIT Press, 2011.

Marosan, Bence Peter. "The Primal Child of Nature - Towards a Systematic Theory of EcoPhenomenology. "Phenomenology and the Human Positioning in the Cosmos II: The Life-world, Nature, Earth. Ed. Anna-Teresa Tymieniecka. Dordrecht: Springer, 2013.

McCool, Gerald A.. "Jacques Maritain: A Neo-Thomist Classic." The Journal of Religion, Vol. 58, No. 4 (October 1978) 380-404.

Nissiotis, Nikos. "Nature and Creation: A Comment on the Environmental Problem from a Philosophical and Theological Standpoint." Toward an Ecology of Transfiguration. Eds. John Chryssavgis and Bruce V. Foltz. New York: Fordham University Press, 2013.
Oltvai, Kristóf. "Bergoglio among the Phenomenologists: Encounter, Otherness, and Church ini Evangelii Gaudium and Amoris Laetitia." Open Theology Vol. 2 (2018): 316-324.

Panteleimon Manoussakis, John. "Physis and Ktisis: Two Different Ways of Thinking of the World." Toward an Ecology of Transfiguration. Eds. John Chryssavgis and Bruce V. Foltz. New York: Fordham University Press, 2013.

Plato. Complete Works. Ed. John M. Cooper. Indiana: Hackett Publishing, 1997.

Pratt, Vernon. Environment and Philosophy. London: Routledge, 1999.

Reeve, C. D. C. Substantial Knowledge: Aristotle's Metaphysics. Indiana: Hackett Publishing, 2000.

Relph, Edward C. Place and Placeness. London: Pion Limited, 1979.

Saha, Debika. "EcoPhenomenological Vision: Balancing the Harmony of the Earth." EcoPhenomenology: Life, Human Life, PostHuman Life in the Harmony of the Cosmos. Eds. William S. Smith, Jadwiga S. Smith, Daniela Verducci. Switzerland: Springer International, 2018.

Skolimowski, Henryk. "EcoEthics as the Foundation of Conservation." Environmentalist 4, (1984): 45-51.

https://doi.org/10.1007/BF01907 293.

Skolimowski, Henryk. Participatory Mind: A New Theory of Knowledge and of the Universe. London: Pinguin Books, 1994.

Szmyd, Jan. "Modern EcoPhilosophy and Phenomenology of Life on Human Positioning in the Cosmos: A.-T. Tymieniecka and Henryk 
Skolimowski in Comparison." Phenomenology and the Human Positioning in the Cosmos II: The Lifeworld, Nature, Earth. Ed. Anna-Teresa Tymieniecka. Dordrecht: Springer, 2013.

Tymieniecka, Anna-Teresa (ed.). Phenomenology and the Human Positioning in the Cosmos II: The Lifeworld, Nature, Earth. Dordrecht: Springer, 2013.

Tymieniecka, Anna-Teresa. Impetus and Equipose in the Life-Strategies of Reason. Dordrecht: Kluwer Academic, 2000.

Tymieniecka, Anna-Teresa. The Phenomenology of Man and of the Human Condition II. Dordrecht: Kluwer Academic Publishers, 1986.

Wood, David. "What is Phenomenology?." EcoPhenomenology: Back to the Earth Itself. Eds. Charles Brown and Ted Toadvine. Albany, NY: SUNY Press, 2003. 